\title{
Long-term water supply planning in an Australian coastal city: Dams or desalination?
}

\author{
Helen Scarborougha, Oz Sahin ${ }^{b}$, Michael G. Porter ${ }^{c}$ and R.A. Stewart ${ }^{b}$ \\ ${ }^{a}$ School of Accounting, Economics and Finance, Deakin University, Warrnambool 3280, Australia \\ ${ }^{b}$ Griffith School of Engineering, Gold Coast Campus, Griffith University, QLD 4222, Australia \\ ${ }^{a}$ School of Accounting, Economics and Finance, Deakin University, Burwood 3125, Australia
}

Email: helen.scarborough@deakin.edu.au

\section{Corresponding author:}

Dr Helen Scarborough

School of Accounting, Economics and Finance, Deakin University, Warrnambool 3280, Australia

Phone: +61 355633547

Email: helen.scarborough@deakin.edu.au

\section{Highlights}

- Interdisciplinary analysis of long term water supply planning incorporating economic, social and environmental variables.

- Comparison of dam and desalination costs

- Sensitivity of planning to social discount rate, water security index, population growth and scale of capital investment

- Over long term, desalination is a more cost effective supply augmentation alternative..

\begin{abstract}
:
Water resource managers and planners are continually involved in defining and evaluating alternative policies to better meet changing water supply conditions and the expectations of society. To undertake such long-term water supply planning, this study developed a novel integrated system dynamics model to combine economic, social and scientific variables and considerations within the planning horizon. Extensive sensitivity analysis for these variables was considered in this long term water resource planning process. The analysis suggests that over a longer time horizon, desalination provides a more viable, cost effective and secure bulk water supply alternative when compared to building large rain-dependent dams.
\end{abstract}

Keywords: Water planning; Desalination; Social discount rate; System dynamics; Water security 


\section{Introduction}

Security of water for urban cities is an increasingly complex issue for water planners. Water management and optimisation is considered to be one of the most important issues to be resolved as water demand and availability vary significantly from year to year (Kondili et al. 2010). Resulting from declining and increasingly variable surface water supply and growing water demand, many urban water utilities are contemplating or have already made additional investments in less rain dependent supply sources (Gao et al. 2014). This paper addresses the research question of determining the combination of rain dependent and rain independent water sources that most efficiently provides water security for a growing urban city. A Systems Dynamics Modelling approach which combines economic, social and environmental variables has been used to explore the sensitivity of water planning to specific variables. The Systems Dynamics Model provides a robust platform for demonstrating interactions between various factors over time (Sahin et al. 2014a; Sahin et al. 2014b).

A strength of this modelling approach is that the sensitivity of the model to the baseline assumptions can be explored. Our aim in this paper is to explore the sensitivity of the model to key assumptions, particularly those regarding economic variables such as the social discount rate and water supply variables such as the water security index. The water security index is an index of the ratio of water storage to annual usage. This measures the storage buffer available as a contingency for low rainfall years. The combination of economic, and environmental variables in the model reflect the interdisciplinary nature of the research. The aim of the sensitivity analysis is to provide policy-makers with in-depth analysis on the life cycle influence of key economic and environmental parameters on the performance of water infrastructure alternatives. Systems' modelling incorporating sensitivity analysis ensures that more informed water infrastructure decisions are made in the context of long term water planning.

The question being addressed is the most efficient means of attaining long term water security that is at minimum average cost. Incorporated in the analysis is the question of the preferred mix or trade-off of cost and security that planners feel meets the needs of the community, given uncertainty of water supply due to rainfall. Economic theory suggests that in long term water projections, the pricing of water should be 
equivalent to the long run marginal cost of the provision of water. Hence, the aim of planning has generally been to secure water at lowest long run marginal cost. A limitation in striving to achieve this goal is the imperfect knowledge which is a feature of the preferences and the constraints of buyers and producers of urban water as well as policy-makers (Freebairn 2013). As discussed by Ghaffour et al (2013) there is a need to develop a structured and transparent procedure for water supply modelling which illustrates the sensitivity of results to economic parameter estimates. The modelling approach of this research builds on this literature by enhancing the information available to policy-makers with the aim of facilitating welfare maximising decisions when determining water infrastructure requirements and planning.

The paper is structured as follows. Section 2 provides the background to the case study. The modelling is outlined in section 3, which includes, the underlying assumptions, results and sensitivity to particular variables. Section four discusses these findings and their implications for future water planning and section five concludes the paper.

\section{Background to the case study}

The millennium drought in south east Australia between 1997 and 2009 led to investment in rain independent water infrastructure in five Australian states (Downie et al. 2014). In Melbourne, which is a rapidly expanding city and the capital of the state of Victoria, the drought led to the decision to invest in a 150GL per annum desalination plant. The investment was part of a \$A4.9 billion plan to secure water supplies in Victoria (Department of Sustainability and Environment 2007). With a population of over 4.2 million and current population growth of over $2 \%$ per annum, community pressure for security of water supply intensified. Hence, a critical aspect of this infrastructure decision was the desire for security of the water supply for the urban population. During much of this period the urban population experienced restrictions on the availability and use of water. The volatility of the water supply is evidenced by the fact that the standard deviation of the annual inflow for Melbourne reservoirs is about 45 per cent of the average annual inflow (Freebairn 2013). 
The nature of this volatility of inflows in the model highlights the importance of including the water security index in the analysis and incorporating the significant difference between the two water options in terms of the degree of water security associated with different infrastructure decisions.

Given that this investment has now been undertaken, there is a period of time before further water augmentation decisions need to be made. This provides the opportunity for reflection of past decisions and planning for the future by examining the issues associated with future water augmentation infrastructure decisions. A comprehensive analysis of future water augmentation decisions needs to include demand management, portfolio choice of additional investment in infrastructure, and the timing and scale of investment in additional supply. These issues are addressed in the following model.

With current projections, particularly regarding population growth and climate variability, there is a looming gap between increasing water consumption and declining water supply in Melbourne. Hence the question arises as to the least cost, most achievable means of meeting these forecast future supply and security constraints.

Rain dependent alternatives to supply augmentation generally come under two headings; the construction of dams to meet water requirements or extraction from groundwater and/or river water supplies. In the case of Melbourne, the latter option is not currently a realistic alternative, given constraints, including political, on using the new pipelines for inter-basin transfers. Thus we have only canvassed the building of dams as a viable rain dependent future water supply for Melbourne. The viability of future dams raises issues such as site availability and environmental impacts and costs and these issues are discussed in section four.

There are two main rain independent alternatives to supply augmentation; investment in desalination and demand management policies such as water restrictions. Research into the willingness of consumers to pay for security of supply suggests that households have significant preferences and willingness to pay to have security of water supply and to avoid the imposition of water restrictions (Gordon et al. 2001; Hensher et al. 2006; Brennan et al. 2007; Grafton and Ward 2008; and Cooper et al. 2012). Willingness to pay to avoid restrictions is shown to increase with the severity 
and duration of restrictions and may be as high as half the current water bill and, as expected, varies considerably between households. In terms of long term water demand and supply, restrictions are not a viable long term alternative for meeting impending water shortages as it is not feasible that demand could be sufficiently reduced to meet constrained supply levels. Similarly, the price elasticity of demand for water is too low for price mechanisms to be applied to reduce demand by the required magnitudes. Hence, this paper focuses on comparison of the predominate rain dependent long term water supply option for Melbourne - the construction of dams and, the viable rain independent alternative- the construction of desalination capacity. The limitations associated with this approach are discussed in Section 4.

\section{Modelling}

\subsection{Baseline assumptions}

The Systems Dynamics Modelling used in this study provides a robust platform for analysing the interactions between variables influencing water demand and supply, and for exploring the sensitivity of the results to the economic, social and environmental assumptions. It is a powerful tool for informing policy-makers seeking to undertake long term planning of water supply augmentation decisions and has been used for long term planning in a range of fields. (For a summary see Sahin et al. 2014.) 
Figure 1: The System Dynamics model: key variables and their causal relations

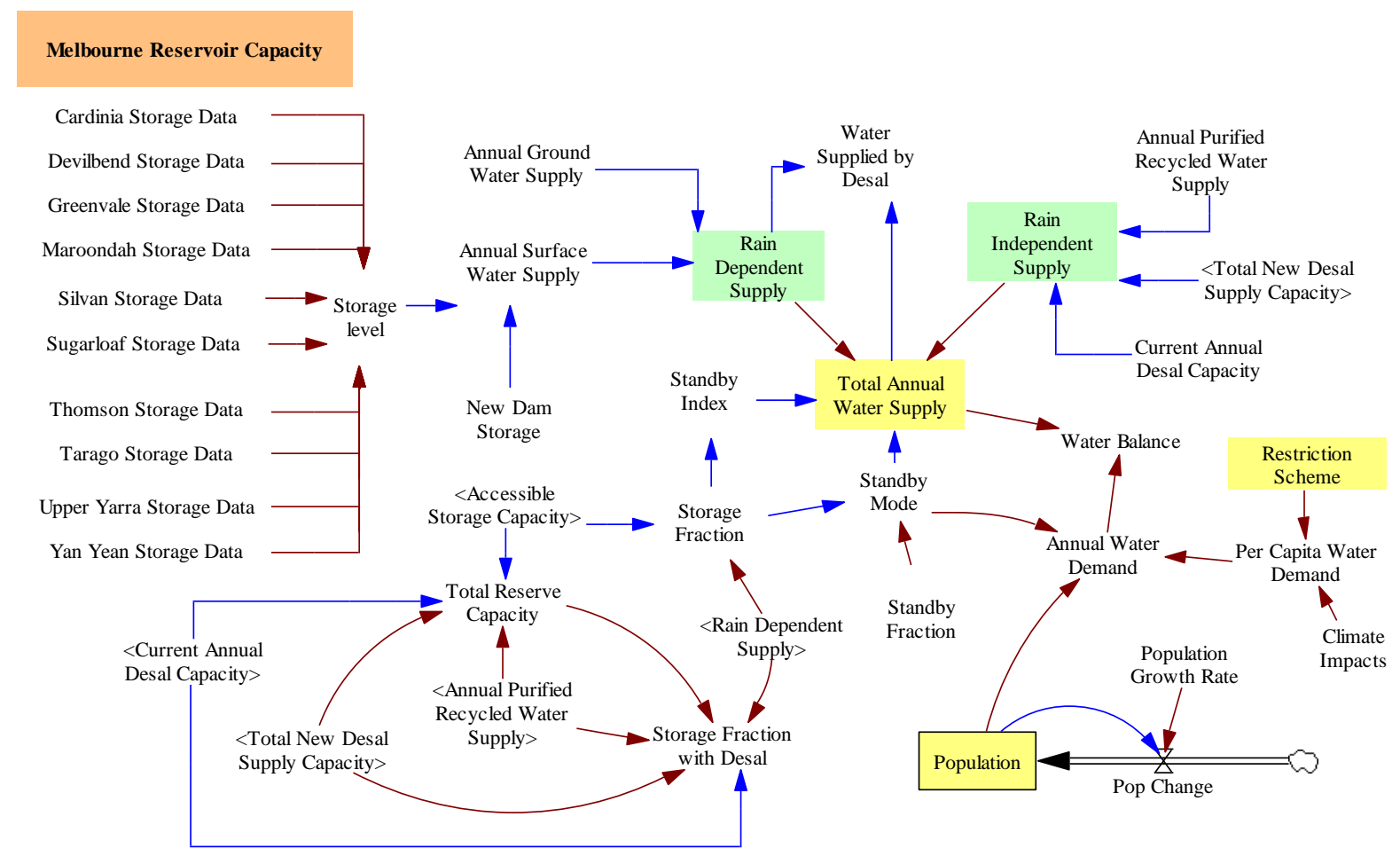

Systems Dynamic Modelling is a powerful methodology and computer simulation modelling approach which can be used for exploration of different options and understanding the long-term implications of management decisions. The system diagram used in this project for analysing the water resource planning situational context for Melbourne is illustrated in Figure 1. The systems dynamic model simulates current and future water supply and demand by considering the effects of factors such as population growth, climate triggered variability in water supply and the potential portfolio mix of rain-dependent dams and rain-independent desalinated water supply. For this analysis, the systems dynamic model was built using Vensim ${ }^{\circledR}$ DSS (Ventana Systems, 2012) with assumptions for parameters and responses drawn from available literature and a range of experts from academia, private consulting firms and government water agencies. The status quo model parameter inputs for the case study city of Melbourne are summarised in Table 1.

The population estimate of 4.25 million is based on Australian Bureau of Statistics estimates of Melbourne's population as at June 30, 2012 (ABS Population 2012). A 
default conservative rate of population growth of $1.25 \%$ has been used based on estimates from the Victorian government (State Government of Victoria 2011). Based on historical usage patterns water use is assumed to be 250 litres per person per day, with 150 litres being based on residential use and 100 litres based on non-residential use (Melbourne Water Authorities 2012). The current dam water supply capacity is 1,812 GL (Australian Bureau of Meteorology 2014) and the current Wonthaggi desalination plant capacity is 150 GL per annum. Although the major dams supplying Melbourne are near full capacity as a result of a few consecutive years of normal rainfall, in the last decade it reached a low of approximately $30 \%$ of full capacity.

Construction and operation of desalination plants require substantial investments and vary region to region (Dawoud 2005). Accordingly, the cost of desalinated water depends upon many factors such as desalination method, the energy source, the water salinity and the size of desalination plant (Karagiannis and Soldatos 2008). From a cost perspective, in this paper, the capital cost of building desalination capacity is assumed to range from $\$ \mathrm{~A} 1.2$ billion in 2013 dollars to $\$ \mathrm{~A} 3.5$ billion depending on plant size, which has been varied from 50GL to $150 \mathrm{GL}$ p.a. For a $100 \mathrm{GL}$ plant, the cost is assumed to be $\$ \mathrm{~A} 2.4$ billion. These estimates are based on recent desalination investment costs in Australia (Productivity Commission 2011) and have been indexed to assume price increases of $2.5 \%$ per annum. A default scale of potentially modular investment in desalination of 50GL has been used in the initial scenarios, and sensitivity to this assumption is included in section 3.5. 
Table 1: Baseline values for Melbourne water supply and demand

\begin{tabular}{|c|c|}
\hline Variable & Baseline Values \\
\hline Population - current & 4.25 million \\
\hline Population growth rate $\%$ & $\begin{array}{l}\text { Varying from }-2.5 \text { to } 2.5 \\
\text { Default }=1.25 \%\end{array}$ \\
\hline Current water use per capita & $\begin{array}{l}250 \mathrm{~L} / \mathrm{p} / \mathrm{d} \text { (Litres/person-day) } \\
(150 \mathrm{residential} / 100 \text { non-residential) }\end{array}$ \\
\hline Dam capacity - current & $1,812 \mathrm{GL}$ \\
\hline Desalination capacity - current & $150 \mathrm{GL}$ \\
\hline Desalination capital costs & $\begin{array}{l}\text { Varying from } \$ A 1.2 b-\$ A 3.5 b^{1} \\
\text { Default }=\$ A 1.2 b^{1}\end{array}$ \\
\hline Desalination operation costs & $\begin{array}{l}0-\$ 182 \mathrm{~m}^{1} \\
\text { (Depending on water order) }\end{array}$ \\
\hline Dam capital costs ${ }^{2}$ & $\begin{array}{l}\text { Varying from } \$ A 1 b \text { to } \$ A b^{1} \\
\text { Default }=\$ A 1.7 b^{1} \text { per } 100 G L\end{array}$ \\
\hline Dam operation costs & $\$ A 0.10-\$ A 0.30^{1}$ \\
\hline Model time bound & 100 year \\
\hline Time interval of simulation & $1 / 4$ year \\
\hline Water security index ${ }^{3}$ & Varying 1 to 6 \\
\hline Social Discount rate $\%$ & $\begin{array}{l}\text { Varying from } 1.5 \text { to } 5.5 \\
\text { Default value }=3.5 \%\end{array}$ \\
\hline Size of new desalination & $\begin{array}{l}\text { Varying from } 50 \text { to } 150 \\
\text { Default value }=50\end{array}$ \\
\hline Size of new dam & $\begin{array}{l}\text { Varying from } 50 \text { to } 150 \\
\text { Default value }=100\end{array}$ \\
\hline
\end{tabular}

\footnotetext{
Notes

${ }^{1}$ Australian dollars $(0.9685$ USD $=1.0$ AUD average for 2013 prices $)$

${ }^{2}$ Moran (2008)

${ }^{3}$ The water security index is the annual demand divided by the accessible storage capacity
} 
The assumed size of new dam capacity also varies from 50 GL to 150GL with a default capital cost of \$A1.7 billion per 100GL. This assumption is based on estimates of dam construction recently undertaken in Queensland (ABC 2006), and estimates of the cost of new dams for Melbourne. According to Sinclair Knight Merz (SKM) (2005) the cost of a new dam duplicating the current Thomson facility on the Mitchell River was an estimated \$A1.35 billion and the reported costs of the sugarloaf scheme \$A1.65 billion. The baseline capital cost assumption for investment in new dam water capacity is considered to be conservative, given the restrictions on land availability within catchments, which is only likely to become more severe with the pressures of population growth and competing demand for water use within catchments.

Operating costs for desalination are varied depending on the extent to which water sourced from desalination is used in the water portfolio. Recent cost decreases in desalination due to improvements in technology have enhanced the viability of desalination as a water supply option. In this analysis, further per unit cost reductions have not been assumed, even though this is possible. For water sourced from dams, operating costs are dependent on piping costs and estimates have been based on current costs. However, these are likely to increase as reductions in land availability may increase distances between water supply and population, therefore increasing piping and pumping (energy) costs.

The time period for the analysis was selected to be 100 years and the modelling indicates how the optimal water portfolio mix changes over time. It is acknowledged that during such a long time span, possible policy reforms, social developments and changes in economic and environmental conditions are likely to occur. For this reason the 100 years is seen as a time bound and the results are presented in a continuous form where changes in the key variables during the time period and at intervening times can be analysed.

It is essential for comparison of costs and benefits over time that future benefits and costs are discounted to allow comparison in terms of net present value. This acknowledges that there is both an opportunity cost of capital and that the community may have preferences about the timing of costs and benefits. To explore the sensitivity of the analysis to the choice of discount rate, the results with the discount 
rate varying between $1.5 \%$ and $5.5 \%$ are shown. These rates are consistent with the variance in the rates used for long term analysis of climate policies (See Scarborough 2011).

The final variable for which assumptions need to be made is the water security index. As indicated, this index reflects the ratio of water storage to annual usage and the storage buffer required against low rainfall years. It has been estimated that for Australian cities this index varies between one and six, with six indicating that to maintain reliable water supply, water storage capacity needs to be six times annual usage to provide reliability of supply given climate variability (Marsden Jacobs, 2006). In 2006, it was estimated that the water security index for Melbourne was three. We have explored the sensitivity of the model to the index varying between one and six and have reported results with an index of three and four ${ }^{1}$.

Given these baseline assumptions, the first column of Table 2 shows the additional water storage capacity that would be required for Melbourne over the next one hundred years. The results show that under the baseline assumption, Melbourne would be forecast to have sufficient water supplies for the next forty years, after which investment in additional water infrastructure would need to be made. The assumptions for economic and population growth are conservative in the baseline model suggesting that additional capacity requirements are likely to be higher and arise sooner than this estimate.

\subsection{Sensitivity to water security index}

In order to explore the sensitivity of the model to individual assumptions we have explored the influence on the model of varying specific assumptions. In each case, all variables other than the variable being analysed have been held constant.

Freebairn (2013) suggests a Lancaster (1971) model of product characteristics be applied in determining decision strategies for infrastructure investment. This approach incorporates security of supply as a component or attribute of consumer water demand functions. Increasing water security increases consumers' utility from water and consumers' are aware that greater security of supply comes at an additional cost.

\footnotetext{
${ }^{1}$ A consideration in judging security is access to river supplies, as in Adelaide where pipelines from the River Murray have enabled Adelaide to have secure water by drawing on the much larger Murray-Darling Basin supplies.
} 
Hence, the analysis in this paper includes a water security index reflecting the ratio of water storage to annual usage and the storage buffer required against low rainfall years.

Table 2: Additional storage capacity required under baseline scenario to maintain water security (GL)

\begin{tabular}{cccc}
\hline Year & \multicolumn{3}{c}{ Additional storage required (GL) } \\
\cline { 2 - 4 } & $\begin{array}{c}\text { Water security index: } 3 \\
\text { Population growth } \\
\text { Water security index: } 4 \\
\text { Population growth: } \\
\text { Current }\end{array}$ & $\begin{array}{c}\text { Water security index: } 4 \\
\text { Population growth: }\end{array}$ \\
Year & $-25 \%$ & $2 \%$ \\
5 & - & - & - \\
10 & - & - & - \\
15 & - & - & - \\
20 & - & - & 180 \\
25 & - & - & 345 \\
30 & - & 162 & 525 \\
35 & - & 316 & 874 \\
40 & - & 482 & 1,215 \\
45 & 158 & 660 & 1,401 \\
50 & 312 & 820 & 1,808 \\
55 & 312 & 989 & 2,187 \\
60 & 477 & 1,170 & 2,693 \\
65 & 656 & 1,323 & 3,065 \\
70 & 815 & 1,483 & 3,683 \\
75 & 984 & 1,829 & 4,137 \\
80 & 1,164 & 2,015 & 4,889 \\
85 & 1,476 & 2,211 & 5,443 \\
90 & 1,645 & 2,523 & 6,360 \\
95 & 1,822 & 2,860 & 7,212 \\
100 & 2,007 & 3,038 & 8,153 \\
& & 3,414 & 9,191 \\
\hline
\end{tabular}

The additional storage capacity required is particularly sensitive to assumptions regarding the water security index. Under the baseline scenario, it is assumed that the future supply will rely on rain dependent supply and there will be no new desalination capacity investment. In Table 2, the sensitivity of future water requirements to assumptions regarding the water security index is illustrated with comparison of projected water shortfalls with a water security index of 3 and a water security index of 4 (columns 1 and 2). The range for this index is based on estimates by Marsden Jacobs (2006) of water security indices for Australian capital cities. As previously indicated, a water security index of 3 is based on the water demand level (per person) 
in 2006. If the 2013 water demand figure is used, this ratio would be 4 which is likely to be a more realistic assumption. This reflects the fact that drought proofing has always been a major justification for investment in water supply capacity in Australia.

If the water security index if assumed to be 4, which we consider more realistic, additional capacity would be required in 25 years' time, rather than the forty years' time result with a water security index of 3 . This clearly illustrates the sensitivity of the model to the assumption regarding the water security index. In either case, these results illustrate the need for long term planning, to meet the challenges of likely water shortfalls between demand and supply. With a water security index of 3 the total additional water supply required over the 100 year period is likely to be an increase in capacity of approximately 2,000 GL and if the water security index is assumed to be four, this rises to 3,400 GL.

The forecast future water shortages show that in the absence of long term water supply augmentation planning, water shortages are likely to occur. The magnitude of the shortages is such that demand management strategies are not a likely viable option for addressing the future imbalance between water demand and supply. There is also evidence to support the argument that the implementation of water restrictions to manage water demand is not economically efficient and can impose substantial welfare losses (Grafton and Ward 2008).

\subsection{Sensitivity to population growth forecast}

The population growth forecast for the baseline scenario is based on the State Government of Victoria's (2011) long term projection of $1.25 \%$ growth per annum. Given the one hundred year period for this analysis, this is considered an appropriate assumption. However, current figures indicate that Melbourne's population is growing at $2.2 \%$ per annum (ABS 2014). For this reason we have explored the sensitivity of the future water supply requirements to the population growth rate assumption. As shown in column three of Table 2, if the population growth rate is $2 \%$ per annum, Melbourne will require additional water capacity in fifteen years and the size of the shortfall between demand and current capacity rises by $170 \%$ to over 9,000 GL. 


\subsection{Sensitivity to the social discount rate}

Economic theory suggests that to incorporate inter-temporal changes and intergenerational equity into a decision-making framework, the future costs and benefits should be discounted and compared in present value terms. However, there is considerable debate in the literature about the appropriate social discount rate and this is reflected in a divergence of approaches in practice. Reviews on discounting issues are provided, for example, in Gollier (2012) and Scarborough (2011).

Despite extensive literature and debate, the choice of social discount rate remains unresolved and long term planning decisions are influenced by social discount rate assumptions. This is particularly apparent in the case of water resource planning where the timing and size of large infrastructure investments influences analysis of water supply alternatives.

Figures 2, 3 and 4 show the sensitivity of the results of the comparison of water supply augmentation costs between dam construction and investing in desalination capacity to assumptions regarding the social discount rate. (Table A1 in the Appendix provides the values for these graphs.) This analysis is based on the status quo assumptions outlined in Table 1 and a water security index of 4 . The impact of social discount rates of $1.5 \%, 3.5 \%$ and $5.5 \%$ have been explored. The Australian government recommends a social discount rate of $7 \%$ with sensitivity analysis at $3 \%$ and $11 \%$ (Department of Finance 2007). However, given the longer time horizon, lower rates have been used in the sensitivity analysis. This is in line with the literature which suggests that lower discount rates are more appropriate over longer time horizons (see, for example, Weitzman 1998). There is also literature to suggest that lower social discount rates are more appropriate for public projects given the lower risk and diversity of risk profile associated with public sector investments (For example, Tietenberg and Lewis, 2012).

As expected, the higher the assumed social discount rate, the lower the present value of the costs of both dam construction and building desalination capacity. With a $1.5 \%$ discount rate, the present value of investment costs over the 100 year period are \$A36.3 billion (2013 dollars) for dam costs compared to \$A22.4 billion for desalination costs (Figure 2). This can be compared with present value costs of \$A13.7 billion for dam costs and \$A10.1 for desalination costs with a 3.5\% social 
discount rate; and \$A6.2 billion for dam costs and \$A6.0 billion for desalination costs with a $5.5 \%$ social discount rate (Figures 3 and 4 ).

In each case, in the short term, the cost of desalination investment in water supply augmentation is higher than the cost of dam construction, however over the longer time horizon, the cost comparison changes in favour of desalination. With a $1.5 \%$ or $3.5 \%$ social discount rate desalination becomes the more favourable option after 35 years and with a $5.5 \%$ social discount rate after 50 years. The lower the assumed social discount rate in the analysis, the more favourable the investment in desalination becomes. As anticipated, the analysis is influenced by the timing and scale of new infrastructure decisions.

Figure 2: Comparison of water supply augmentation costs with $1.5 \%$ social discount rate.

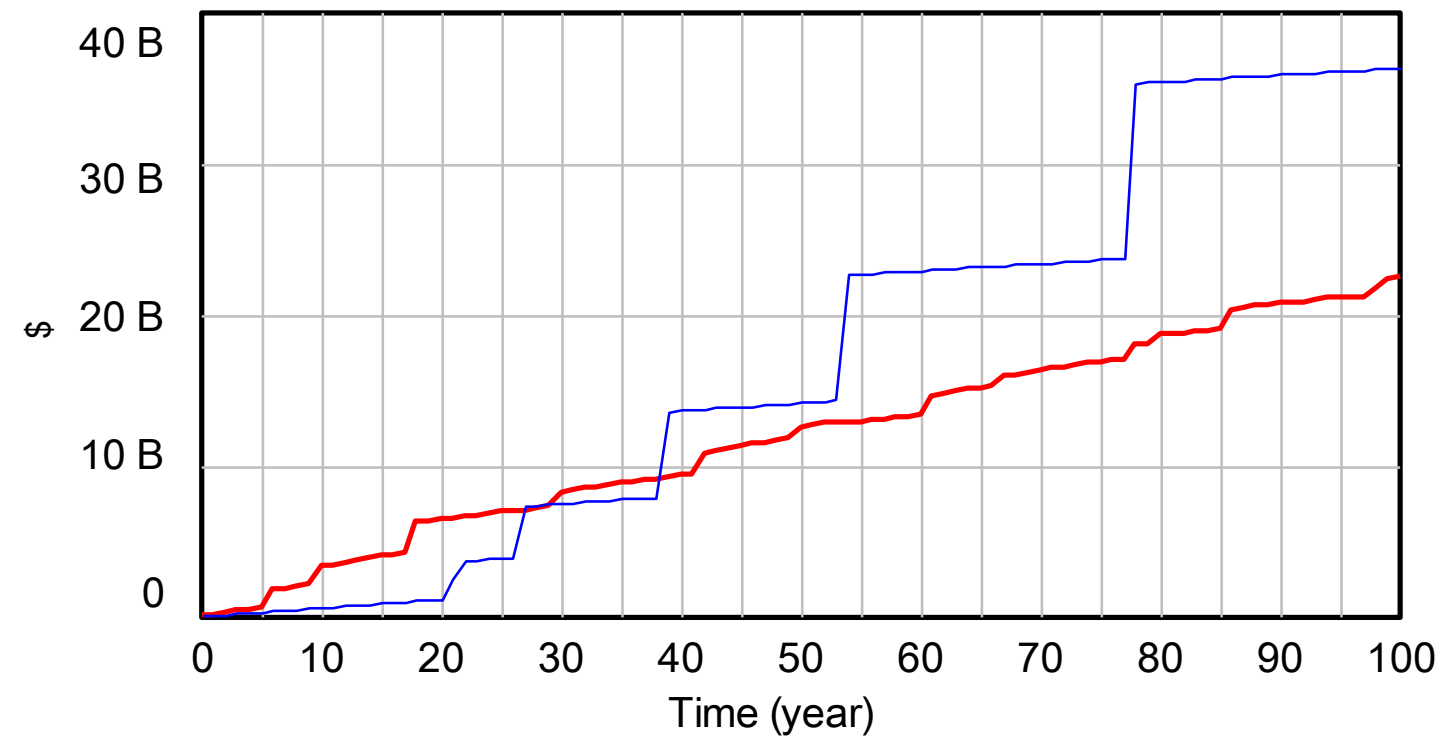

NPV of Dam Cost : Scn2 DiscountRate15 NPV of Desal Cost : Scn2 DiscountRate15 
Figure 3: Comparison of water supply augmentation costs with $3.5 \%$ social discount rate.

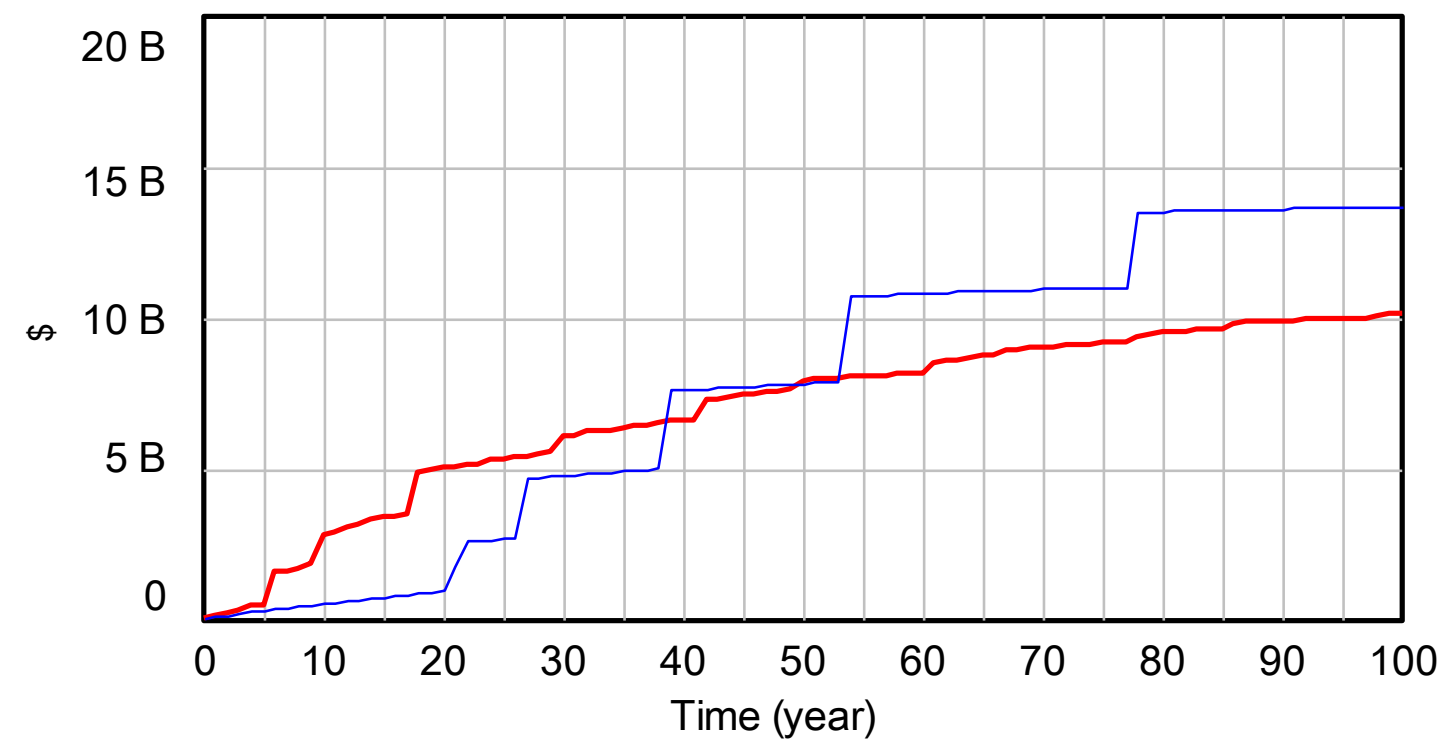

NPV of Dam Cost : Scn3 DiscountRate35

NPV of Desal Cost : Scn3 DiscountRate35

Figure 4: Comparison of water supply augmentation costs with $5.5 \%$ social discount rate.

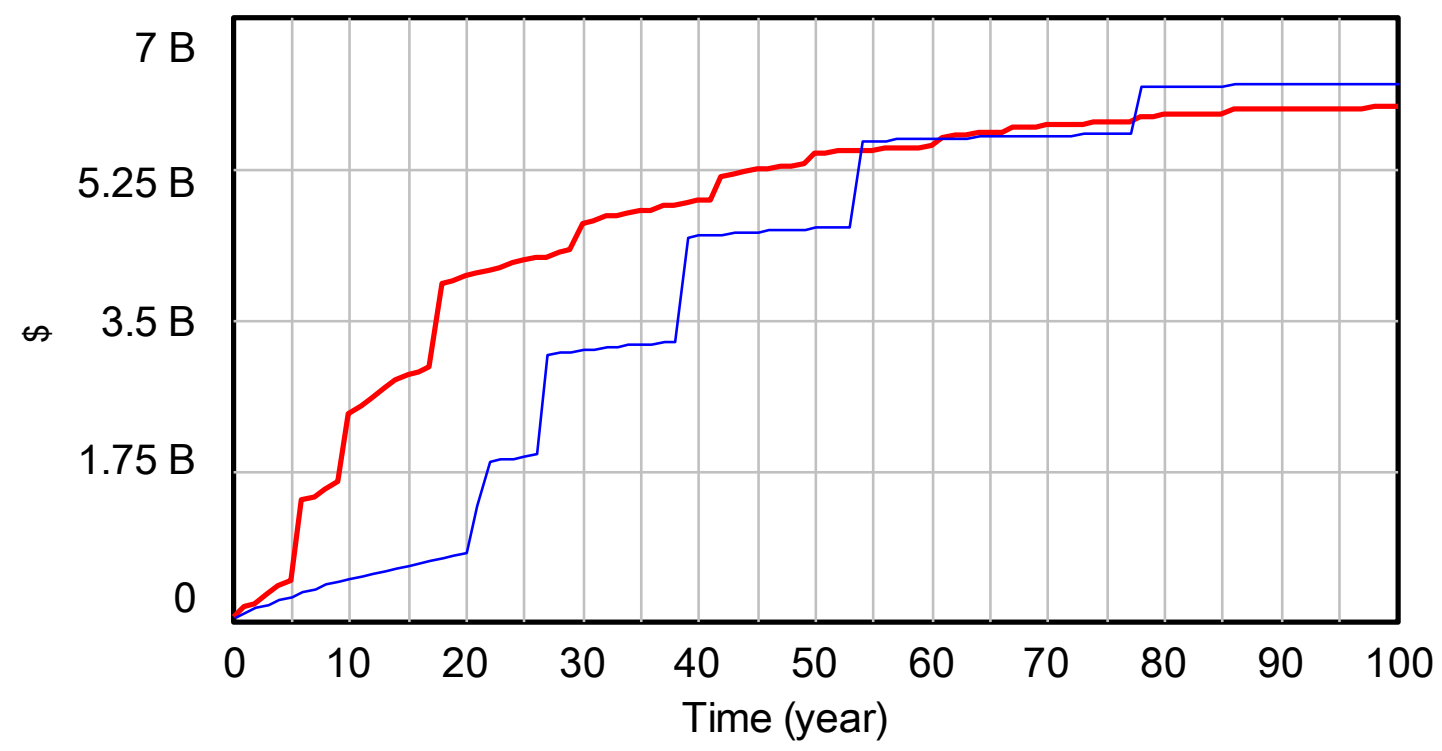

NPV of Dam Cost : Scn4 DiscountRate55

NPV of Desal Cost : Scn4 DiscountRate55 


\subsection{Sensitivity to the scale of capital investment}

Comparison of the costs of supply augmentation through dam construction or desalination is also sensitive to the timing and scale of the investment in augmentation of the water supply. Clarke (2013) highlights this issue as a choice between flexibility and scale. Building a smaller scale plant has the advantage of not tying up large amount of capital, however the trade-off is the loss of scale economies in constructing a large-scale plant.

Table 3 details how the cost comparison between dam construction and desalination is influenced by the size of the desalination plant investment. For Table 3 the assumed social discount rate is $1.5 \%$. The net present values (NPV) have been calculated using Equation 1:

$$
N P V(i, N)=\sum_{t=0}^{N} \frac{C}{(!+t)^{t}}
$$

Where; $t$ is the time horizon, $i$ is the social discount rate, and $\mathrm{C}$ is the cost.

The ability to augment supply as water scarcity arises by "blocks" of increased desalination capacity as a method of supply augmentation has intuitive advantages as it requires more frequent, but smaller investments. However, this analysis is highly dependent on the social discount rate applied in calculating net present value comparisons. With a $1.5 \%$ discount rate, the net present value of investment in desalination capacity to meet the water requirements over the one hundred year period is lower if the investment is made in $150 \mathrm{GL}$ blocks of increased capacity than in smaller $50 \mathrm{GL}$ desalination investments. With a higher discount rate this result changes as it is advantageous to bring investment expenditure forward. 
Table 3: Water supply augmentation costs sensitivity to size of desalination plant (Billion \$A)

\begin{tabular}{|c|c|c|c|c|c|c|}
\hline \multirow[b]{2}{*}{ Year } & \multicolumn{3}{|c|}{ NPV of Dam Cost } & \multicolumn{3}{|c|}{ NPV of Desal Cost } \\
\hline & $\begin{array}{c}\text { Dam size } \\
50 \mathrm{Gl}\end{array}$ & $\begin{array}{c}\text { Dam size } \\
100 \mathrm{Gl}\end{array}$ & $\begin{array}{c}\text { Dam size } \\
\text { 150Gl }\end{array}$ & $\begin{array}{c}\text { Plant size } \\
50 \mathrm{Gl}\end{array}$ & $\begin{array}{c}\text { Plant size } \\
100 \mathrm{Gl}\end{array}$ & $\begin{array}{c}\text { Plant size } \\
\text { 150Gl }\end{array}$ \\
\hline Base & 0.06 & 0.06 & 0.06 & 0.05 & 0.05 & 0.05 \\
\hline 5 & 0.34 & 0.34 & 0.34 & 0.53 & 0.53 & 0.53 \\
\hline 10 & 0.62 & 0.62 & 0.62 & 3.28 & 3.15 & 1.11 \\
\hline 15 & 0.90 & 0.90 & 0.90 & 4.06 & 3.93 & 1.65 \\
\hline 20 & 1.17 & 1.17 & 1.17 & 6.43 & 6.29 & 4.72 \\
\hline 25 & 3.88 & 3.88 & 3.88 & 6.91 & 6.77 & 5.18 \\
\hline 30 & 7.51 & 7.51 & 7.51 & 8.27 & 7.37 & 7.93 \\
\hline 35 & 7.77 & 7.77 & 7.77 & 8.83 & 7.90 & 8.53 \\
\hline 40 & 13.65 & 13.65 & 13.65 & 9.31 & 8.35 & 9.04 \\
\hline 45 & 13.91 & 13.91 & 13.91 & 11.25 & 10.24 & 9.71 \\
\hline 50 & 14.17 & 14.17 & 14.17 & 12.57 & 12.07 & 10.41 \\
\hline 55 & 22.66 & 22.66 & 22.66 & 12.91 & 12.42 & 10.74 \\
\hline 60 & 22.91 & 22.91 & 22.91 & 13.36 & 12.86 & 11.15 \\
\hline 65 & 23.16 & 23.16 & 23.16 & 15.15 & 14.66 & 13.32 \\
\hline 70 & 23.40 & 23.40 & 23.40 & 16.27 & 15.33 & 13.96 \\
\hline 75 & 23.64 & 23.64 & 23.64 & 16.86 & 15.89 & 14.49 \\
\hline 80 & 35.41 & 35.41 & 35.41 & 18.64 & 18.00 & 16.21 \\
\hline 85 & 35.64 & 35.64 & 35.64 & 19.08 & 18.44 & 16.63 \\
\hline 90 & 35.88 & 35.88 & 35.88 & 20.71 & 19.73 & 18.18 \\
\hline 95 & 36.10 & 36.10 & 36.10 & 21.09 & 20.10 & 18.55 \\
\hline 100 & 36.33 & 36.33 & 36.33 & 22.42 & 21.70 & 19.85 \\
\hline
\end{tabular}

\subsection{Sensitivity to land availability}

A further concern regarding the baseline assumptions is the capital and operating costs associated with providing additional dam capacity. The feasibility of securing new dam sites in Victoria that can feasibly service the Melbourne populace, is limited. Moreover, with strong population growth in the city and surrounding regional areas expected over the coming decades, the difficulty in securing land for a dam diminishes, and where feasible, the costs to procure such land will escalate. Land 
availability, particularly of required catchment-size and quality, is increasingly limited. Land costs are rising and environmental pressures increasing. For these reasons, we tested the sensitivity to a $1 \%$ or $2 \%$ per annum rise in the costs associated with using dams to meet future water shortfalls (Figure 5). The range of $1 \%$ to $2 \%$ for the sensitivity analysis was applied as the average of the Gross Domestic Product deflator, a measure of price rises, between 1990 and 2014 was 1.5\% (ABS 2014).

In the baseline scenario, the comparison between dam costs and desalination costs over the 100 years is \$A36 billion compared to \$A22 billion. With a $1 \%$ increase in dam costs the net present value of the dam cost rises to \$A60 billion and with a $2 \%$ increase it rises to a net present value of \$A104 billion.

Figure 5: Sensitivity to increases in catchment costs for additional dam capacity

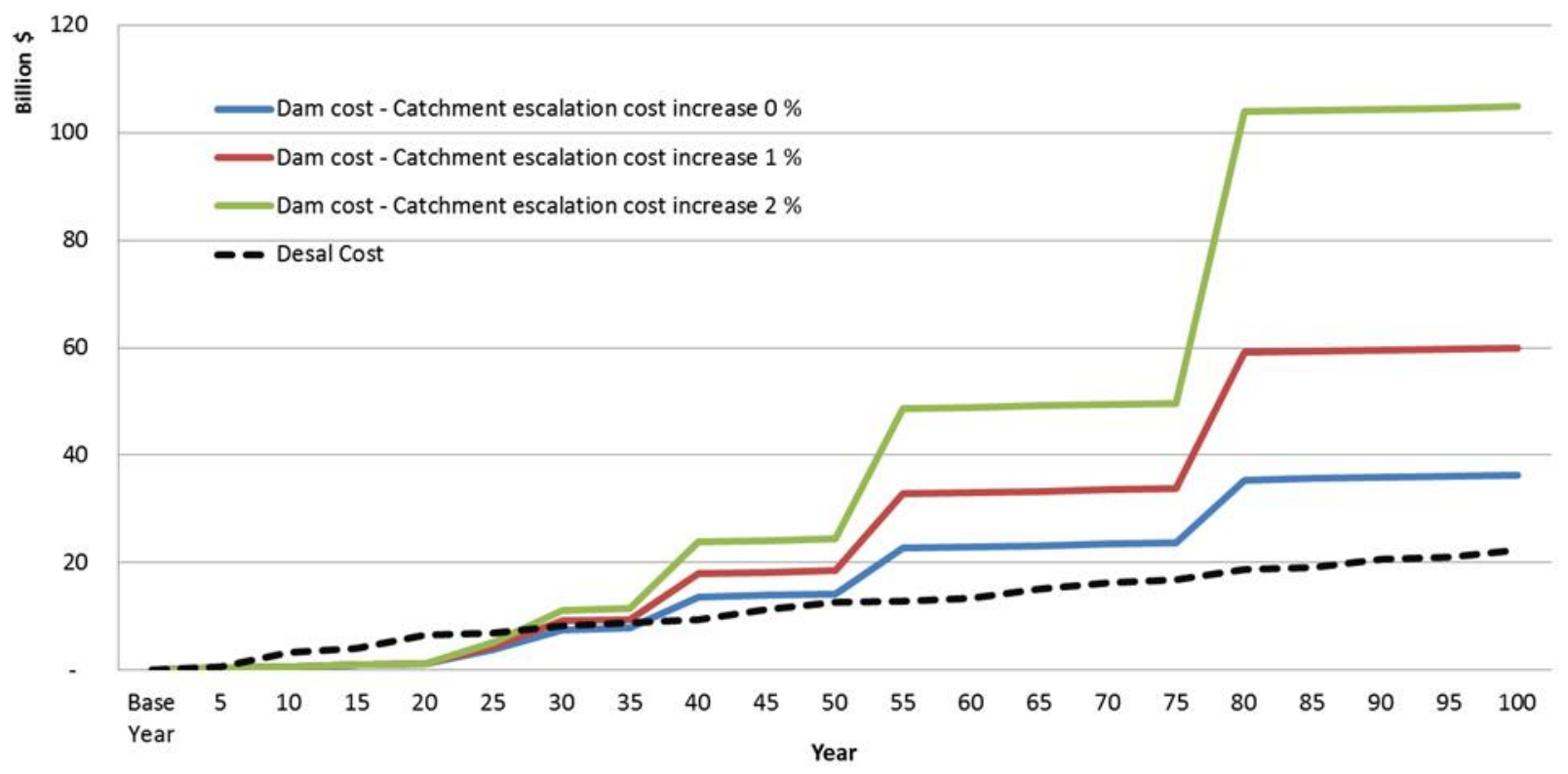

\subsection{Further discussion}

A key factor to be considered in this analysis is climate and rainfall variability. While rainfall projections impact water supply, temperature projections also have a significant impact on water demand with high temperatures raising demand. In the baseline model rainfall and temperature projections have been based on average past rainfall and temperatures. Potential future variability in climate, temperature, and 
rainfall levels have not been included in the modelling, although these could be incorporated. This modelling decision was made so that the sensitivity to the identified factors could be isolated and explored. While the introduction of the water security index to the model introduced the question of the security of dam water supplies at any time, it does not address the question of the timing of rainfall following dam construction. It is possible that a dam could be constructed and if this coincided with a drought, there may not be enough rain to fill the dam and it could take some time to achieve the desired water capacity.

As well as climate impacts, the annual per capita demand for water is also assumed to be a function of the water price and based on previous literature the elasticity of water demand applied in the model is assumed to be -0.5 (See for example, Olmstead et al. 2007; Hoffman et al. 2006). In order to explore the sensitivity to the factors identified, pricing regimes have not been employed in the model to influence demand. But, as Sahin et al. (2014) have shown, a temporary drought pricing regime not only defers costly bulk supply infrastructure but also generates greater price stability and, if necessary provides financing capacity not generated through traditional pricing approaches.

There is also the issue of uncertainty and a priori decision making. Previous investment in desalination has effectively provided a short term insurance policy for Melbourne, and a key question becomes the cost of future water insurance and the willingness of the community to pay for water security. The Productivity Commission Inquiry (2011) suggested that investments in desalination in Australia have achieved water supply security but at an excessive cost. However, this judgement depends on assumptions about the treatment of uncertainty and the willingness of the community to pay for water security. Clarke (2014) questions whether an estimated \$A38 per capita, based on the Productivity Commission findings, may in fact be a reasonable cost for providing a rainfall independent secure source of water supply. This analysis indicates that there is time for future planning and community discussion regarding desired levels of water security. It is a discussion which needs to occur.

Also critical to this analysis is the possibility that land will not be available for dam construction. Clarke (2013) shows that if only a limited or zero stock of extra dams can be constructed, given the risk associated with dams subsequently being filled, "the 
marginal utility of water (its scarcity value) will be high boosting the case for desalination.”

The issue of technological change also needs to be addressed. Previous reductions in operating costs due to reverse osmosis and improved technology have increased the viability of desalination as a bulk water option. Whether such gains in efficiency can be extrapolated to the future and their impact on future decision-making is ambiguous. If it is thought that technology will continue to improve, this may contribute to a case for deferring new desalination investment to capture the advantage of future cost decreases (Clarke 2013). Conversely, rising energy costs could increase future desalination operating costs.

And finally, the issue of water quality has not been addressed. In this analysis, water has been treated as a homogenous product, when in fact, desalination technologies have the ability to provide better quality water than can be provided from alternative sources.

\subsection{Conclusion}

In an environment of future uncertainties, this paper seeks to investigate the cost comparisons of long term water planning for a large urban city, Melbourne, where strong population growth and climate variability have strained current water supplies. The analysis suggests that over a longer time horizon, desalination provides a viable, cost effective and secure water supply alternative. The optimal extent and timing of new infrastructure is dependent on assumptions regarding the economic and social variables such as the social discount rate, the scale of infrastructure investment, the availability and price of land associated with dams and the level of water security desired by the community.

Coastal Australian cities are exposed to long-term dry and wet weather cycles of 3-7 years driven by El Nino and La Nina conditions in the Pacific Ocean. As revealed in this study, this characteristic means that the existing dam storages servicing the major coastal cities of the country, that were previously sufficient for the historically lower populations over the long dry periods, may be better supplemented by desalination expanded supply in the future. This will result in a more balanced and cost-effective portfolio of rain-dependent and rain-independent bulk supply solutions to service the 
rapidly growing populations of these cities and also the increasingly variable climatic conditions.

\section{ACKNOWLEDGEMENTS}

This research is part of a study on desalinated water in Australian bulk water supply networks, funded by a grant from the National Centre of Excellence in Desalination Australia (NCEDA) to the Alfred Deakin Research Institute (ADRI) at Deakin University, in a project jointly managed with the Smart Water Research Centre at Griffith University, and with technical cooperation from AECOM Ltd. 


\section{References}

Australian Broadcasting Commission (ABC) 2006, Water facts: Queensland dams, available at:

http://www.abc.net.au/water/stories/s1679961.htm, Accessed June 2014.

Australian Bureau of Meteorology, 2014 Water storage, Available at: http://water.bom.gov.au//waterstorage/awris/\#urn:bom.gov.au:awris:common:cod elist:region.city:melbourne, Accessed June 2014.

Australian Bureau of Statistics (ABS), 2012, Population Estimates.

Australian Bureau of Statistics (ABS), 2014 Regional Population Growth, Australia, 2012-13, available at:

http://www.abs.gov.au/ausstats/abs@.nsf/Products/3218.0 2012-

13 Main+Features Victoria? OpenDocument\#PARALINK3, Accessed June 2014

Australian Bureau of Statistics (ABS), 2014 Australian National Accounts: National Income, Expenditure and Product, available at: http://www.abs.gov.au/AUSSTATS/abs@.nsf/DetailsPage/5206.0Jun\%202014?OpenDoc ument\#Publications, Accessed October, 2014.

Brennan, D., Tasuwan, S. and Ingram, G., 2007 "The welfare costs of outdoor water restrictions", Australian Journal of Agricultural and Resource Economics, 51 (3), 243-262.

Clarke, Harry, 2013 "Planning urban water investments with an uncertain climate" Economic Papers, 32 (4), 426-439.

Clarke, Harry, 2014 "Evaluating Infrastructure Projects under Risk and Uncertainty: A Checklist of Issues, Economic Review, 47 (1), 147-156.

Cooper B, Rose, J. and Crase, L 2012 "Does anybody like water restrictions? Some observations on Australian urban communities", Australian Journal of Agricultural and Resource Economics, 56 (1), 61-81

Dawoud, M. A. 2005. "The role of desalination in augmentation of water supply in GCC countries". Desalination, 186, 187-198.

Department of Sustainability and Environment, 2007 Our Water Our Future; The Next Stage of the Government's Water Plan, State Government of Victoria.

Downie, D., Porter, M, Scarborough, H. Sahin, O and Stewart R 2014 "Drought and Desalination: Melbourne Water Supply and Development choices in the $21^{\text {st }}$ Century". Paper presented to Conference of the European Desalination society, Cyprus.

Freebairn, John 2013 "Imperfect knowledge and urban water decisions, Economic Papers, 32 (1), 32-40.

Gao, L., Connor, J. D. \& Dillon, P. 2014. "The Economics of Groundwater Replenishment for Reliable Urban Water Supply”. Water, 6, 1662-1670 
Ghaffour, N. Missimer, T. and Amy, G 2013 "Technical review and evaluation of the economics of water desalination: current and future challenges for better water supply sustainability, Desalination, 309, 197-207.

Gollier, C. 2012 "Pricing the planet's future: the economics of discounting in an uncertain world", Princeton University Press.

Gordon, J., Chapman, R. and Blamey, R. 2001 "Assessing the Options for the Canberra Water Supply: An Application of choice Modelling" in Bennett, J and Blamey, R (eds), The Choice Modelling Approach to Environmental Management, Edward Elgar, Cheltenham, UK.

Grafton and Ward 2008 "Prices versus Rationing: Marshalling Surplus and Mandatory Water Restrictions, The Economic Record, 84, Special Issue S57-S65.

Heberger M 2012 Australia's Millennium Drought: Impacts and Responses, in P.H. Gleik (ed) The World's Water, Pacific Institute for Studies in Development, Environment and Security.

Hensher, D., Shore, N and Train, K. 2006 "Water Supply Security and Willingness to Pay to Avoid Drought Restrictions", Economic Record, 82, 56-66.

Hoffmann, M., Worthington, A. and Higgs, H. "Urban water demand with fixed volumetric charging in a large municipality: the case of Brisbane", Australia, Australian Journal of Agricultural and Resource Economics, 50, 347-359.

Institute of Public Affairs, 2008 "Water supply options for Melbourne: As examination of costs and availabilities of new water supply sources for Melbourne and other urban areas in Victoria", Occasional Paper.

Karagiannis, I. C. \& Soldatos, P. G. 2008. "Water desalination cost literature: review and assessment". Desalination, 223, 448-456.

Kondili, E., Kaldellis, J. K. \& Papapostolou, C. 2010. “A novel systemic approach to water resources optimisation in areas with limited water resources". Desalination, 250, 297-301.

Lancaster, K. 1971, Consumer Demand: A New Approach. Columbia University Press, New York.

Loucks D. P. 20?? Risk and uncertainty in water resources planning and management; a basic introduction in ,..... edited by Grafton

Marsden and Pickering, 2006 "Securing Australia's Urban Water Supplies”, A discussion paper prepared for the Department of Prime Minister and Cabinet. Marsden Jacob Associates.

Melbourne Water Authorites, Water Outlook for Melbourne 2012. Available at: http://www.depi.vic.gov.au/_data/assets/pdf_file/0005/176351/4486-WaterOutlook-1-Dec-2012.pdf 
Moran A (2008) Water supply options for Melbourne - An examination of costs and availabilities of new water supply sources for Melbourne and other urban areas in Victoria. Institute of Public Affairs, Melbourne, Australia

Olmstead, S.M., Hanemann, W.M., Stavins, R.N. 2007 "Water demand under alternative price structures", Journal of Environmental Economics and Management, 54, 181-198

Productivity Commission 2011 Australia's Urban Water Sector, Productivity Commission Inquiry Report, Commonwealth of Australia, Melbourne.

Sahin, O., Stewart, R. and Porter, M 2014a "Water security through scarcity pricing and reverse osmosis: a system dynamics approach", Journal of Cleaner Production, Forthcoming.

Sahin, O., Siems, R., Stewart, R. and Porter, M 2014b "Paradigm shift to enhanced water supply planning through augmented grids, scarcity pricing and adaptive factory water: A system dynamic approach" Environmental Modelling and Software, Forthcoming.

Scarborough, H 2011 "Intergenerational equity and the social discount rate" The Australian Journal of Agricultural and Resource Economics, Vol 55, pp145-158.

Sinclair, Knights, Mertz, 2005 "Determination of the minimum environmental water requirements for the Yarra River",

State Government of Victoria, 2011, "Living Melbourne, Living Victoria”,

Tientenberg, T and Lewis, L 2012 Environmental and Natural Resource Economics, $9^{\text {th }}$ Edition, Pearson

Ventana System 2012 Vensim DSS 6.0b ed. Ventana Systems Inc., Harvard, MA.

Weitzman M 1998 "Why the far-distant future should be discounted at its lowest possible rate", Journal of Environmental Economics and Management, 36, 201208. 


\section{APPENDIX}

Table A1: Water supply augmentation costs sensitivity to social discount rate

\begin{tabular}{|c|c|c|c|c|c|c|}
\hline \multirow[b]{2}{*}{$\begin{array}{l}\text { Time } \\
\text { (year) }\end{array}$} & \multicolumn{3}{|c|}{ NPV of Dam Cost (\$AUD) } & \multicolumn{3}{|c|}{ NPV of Desalination Cost (\$AUD) } \\
\hline & $\begin{array}{c}\text { Discount Rate } \\
1.5 \%\end{array}$ & $\begin{array}{c}\text { Discount Rate } \\
3.5 \%\end{array}$ & $\begin{array}{c}\text { Discount Rate } \\
5.5 \%\end{array}$ & $\begin{array}{c}\text { Discount Rate } \\
1.5 \%\end{array}$ & $\begin{array}{c}\text { Discount Rate } \\
3.5 \%\end{array}$ & $\begin{array}{c}\text { Discount Rate } \\
5.5 \%\end{array}$ \\
\hline 0 & $57,312,192$ & $56,204,712$ & $55,139,220$ & $49,996,924$ & $49,030,800$ & $48,101,304$ \\
\hline 5 & $341,762,656$ & $319,423,328$ & $299,253,024$ & $526,058,336$ & $490,550,176$ & $458,441,376$ \\
\hline 10 & $622,727,232$ & $555,248,448$ & $498,002,112$ & $3,284,401,664$ & $2,805,080,576$ & $2,409,687,296$ \\
\hline 15 & $900,248,640$ & $766,530,880$ & $659,816,896$ & $4,062,005,248$ & $3,396,381,184$ & $2,861,973,504$ \\
\hline 20 & $1,174,369,024$ & $955,824,896$ & $791,560,960$ & $6,429,423,616$ & $5,028,620,288$ & $3,995,545,088$ \\
\hline 25 & $3,877,362,176$ & $2,693,560,832$ & $1,918,479,872$ & $6,910,969,856$ & $5,328,434,176$ & $4,184,039,936$ \\
\hline 30 & $7,506,211,840$ & $4,791,942,144$ & $3,144,749,824$ & $8,267,327,488$ & $6,077,483,008$ & $4,602,610,688$ \\
\hline 35 & $7,770,377,216$ & $4,928,073,216$ & $3,215,849,728$ & $8,830,885,888$ & $6,367,404,032$ & $4,753,784,320$ \\
\hline 40 & $13,654,181,888$ & $7,626,275,840$ & $4,471,861,248$ & $9,309,306,880$ & $6,590,569,472$ & $4,859,473,920$ \\
\hline 45 & $13,911,912,448$ & $7,735,546,880$ & $4,518,991,360$ & $11,246,596,096$ & $7,421,900,800$ & $5,222,130,176$ \\
\hline 50 & $14,166,484,992$ & $7,833,445,376$ & $4,557,362,688$ & $12,565,633,024$ & $7,919,174,656$ & $5,413,283,840$ \\
\hline 55 & $22,663,292,928$ & $10,740,333,568$ & $5,572,515,840$ & $12,910,776,320$ & $8,040,193,536$ & $5,456,603,136$ \\
\hline 60 & $22,911,664,128$ & $10,818,915,328$ & $5,597,950,976$ & $13,356,292,096$ & $8,180,507,136$ & $5,501,824,000$ \\
\hline 65 & $23,156,989,952$ & $10,889,319,424$ & $5,618,659,328$ & $15,147,166,720$ & $8,706,179,072$ & $5,659,886,592$ \\
\hline 70 & $23,399,311,360$ & $10,952,396,800$ & $5,635,519,488$ & $16,272,797,696$ & $9,001,437,184$ & $5,739,382,272$ \\
\hline 75 & $23,638,663,168$ & $11,008,909,312$ & $5,649,246,208$ & $16,859,807,744$ & $9,140,212,736$ & $5,773,135,360$ \\
\hline 80 & $35,411,054,592$ & $13,528,897,536$ & $6,204,833,792$ & $18,642,391,040$ & $9,517,660,160$ & $5,855,502,336$ \\
\hline 85 & $35,644,579,840$ & $13,574,259,712$ & $6,213,933,056$ & $19,084,967,936$ & $9,602,953,216$ & $5,872,477,184$ \\
\hline 90 & $35,875,237,888$ & $13,614,901,248$ & $6,221,341,184$ & $20,707,639,296$ & $9,897,005,056$ & $5,927,557,120$ \\
\hline 95 & $36,103,069,696$ & $13,651,312,640$ & $6,227,373,056$ & $21,088,147,456$ & $9,957,619,712$ & $5,937,563,648$ \\
\hline 100 & $36,328,112,128$ & $13,683,935,232$ & $6,232,283,136$ & $22,420,559,872$ & $10,148,676,608$ & $5,966,004,224$ \\
\hline
\end{tabular}

